\title{
PENSION PLANS AND EMPLOYEE CONTRIBUTIONS:
} TUTIAHV. TUTIAH*

\author{
E. DIANE PASK**
}

\section{INTRODUCTION}

Pension plans are of increasing importance as an asset subject to matrimonial property division. Accordingly, lawyers are finding it necessary to develop an understanding of the concepts used in the valuation of pension plans in order to appreciate the material coming to them or their clients from pension plan administrators, actuaries and accountants.

This paper will discuss the accumulated contributions of an employee toward his pension plan and the relationship those contributions bear to the value of the accumulated pension benefits as a whole, using as a vehicle the recent Manitoba Court of Appeal decision in Tutiah v. Tutiah.' While the trial and appellate decisions turn upon the issue of the enforceability of domestic contracts, the case is highly illustrative of the difficulties commonly encountered by lawyers when dealing with pensions in the context of marital estate settlements.

\section{TUTIAH v. TUTIAH}

Mr. Tutiah was a man struggling with a mid-life employment crisis. $\mathrm{He}$ had been an electronics teacher in the Manitoba public school system for 18 years. However, school enrollment was down and he felt insecure about his job. As well, he was tired of dealing with teenagers. In June, 1981, when he was 52 years old, he decided to take a "year out" in order to think things over. That was the last time he made any contributions to his pension plan, the Manitoba Teachers Retirement Allowances Fund, which provided for a pension, other benefits and, in addition, had some indexing provisions.

At the end of the year Mr. Tutiah decided to go into real estate and anticipated a few economically lean years. Throughout that year a number of financial discussions had taken place between husband and wife in order to clarify the effect of this employment change on their financial circumstances. In July, 1982, Mrs. Tutiah, a registered nurse, unexpectedly moved out of the marital home after 23 years of marriage.

Subsequently Mrs. Tutiah told her husband that she would accept $\$ 40,000.00$ in satisfaction of her property interests. At this time, Mrs. Tutiah, but not Mr. Tutiah, had made a financial disclosure and Mrs. Tutiah was unaware of the value of her husband's bank accounts, R.R.S.P.s and pension benefits. Mrs. Tutiah's lawyer had advised her to obtain disclosure from her husband before reaching a settlement of the marital property but Mrs. Tutiah apparently wanted a speedy settlement and, perhaps, a settlement with an attendant low legal bill. Certainly, at the

- Prepared with the assistance of research and materials gathered for the Pension Plans and Employment Benefits Project, Faculty of Law, University of Calgary; funded by The Alberta Law Foundation; Figures 1 and 2 were prepared by Keith McComb, F.S.A., F.C.I.A., Consulting Actuary to the Project.

- Associate Professor, Faculty of Law, University of Calgary, Project Director.

1. (1986) 48 R.F.L. (2d) 337 (Man. C.A.); affg. (1985) 42 R.F.L. (2d) 357 (Q.B.). 
trial held to determine whether the settlement should be set aside, the judge was of the view that there were no facts indicating that Mrs. Tutiah had been forced into making a speedy arrangement by need or distress. ${ }^{2} \mathrm{Her}$ offer was accepted by Mr. Tutiah without any disclosure of assets on his part.

Subsequently, Mrs. Tutiah discussed the matter with friends and decided that she should have had disclosure; she retained a new lawyer and sued to set aside the agreement. Mr. Tutiah not only relied upon the agreement but continued to resist providing full financial disclosure. Finally in August, 1984, an order was obtained that required Mr. Tutiah to provide the information.

The Board which managed the pension fund sent a letter which, as subsequent events have shown, is indicative of the problems that arise when dealing with pension plans. The Board is reported to have stated in that letter that: "Contributions credited to Mr. Tutiah's account, representing 18 years of service for pension purposes, totalled $\$ 14,701.55$. ." $^{3}$ The Board advised that the provincial government was responsible for payment of one-half of all pension costs as they came due and that the province assumed the cost of certain other related pension plan benefits. In April, 1984, prior to the trial of the action, Mr. Tutiah had retired at age 55 and had started receiving his pension benefits in an amount over $\$ 500.00$ per month for life.

When the matter of the validity of the agreement came to trial in October, 1984, the parties agreed that out of a total net asset base of $\$ 192,174.00$, the wife had settled for some $\$ 25,000$.00 less than she would have received under an equal split of the assets. This calculation included the valuation of the pension at $\$ 14,701.00$; the letter from the pension Board was entered as an exhibit. The trial judge declined to set aside the agreement and the wife appealed.

It was not until the matter reached the Court of Appeal that the value attached to the pension was questioned. That occurred when the appellate bench inquired about the statement of assets and discovered that everyone (with the possible exception of Mr. Tutiah) still valued the pension at $\$ 14,701.00$. $^{4}$ Two of the appellate judges, Matas and Huband JJ.A., went to some pains to point out that a benefit paying over $\$ 500.00$ per month for life could not be represented by a valuation of $\$ 14,701.00$ and suggested that the total value of the benefits under the plan could have been determined in 1981. ${ }^{5}$ As Huband J.A. pointed out:" "Lawyers for both parties were content to value the asset simply on the basis of what the husband had paid into the pension fund, and not on the value of what would be paid out to the husband by way of benefits in future years."

In the result, the "totalled contributions" of $\$ 14,701.00$ represented only a mathematical addition of Mr. Tutiah's personal contributions. That figure did not include any credit of interest and did not include any credit

2. (1985) 42 R.F.L. (2d) 357 at 368.

3. (1986) 48 R.F.L. (2d) 337 at 352.

4. Id. at $350,352$.

5. Id. Matas J.A. at 353 and Huband J.A. at 364.

6. Id. at 364 . 
of employer contributions. Thus, the $\$ 14,701.00$ figure could be expected to be a relatively small proportion of the actual value of the accumulated benefits package.

\section{TYPES OF PENSION PLANS}

Mr. Tutiah's pension plan was of the type categorized as a "defined benefit" plan which means that the amount of the pension is determined by the benefit formula in the pension plan itself and does not depend on any amount of money held in a particular account for the employee. This formula takes into account the length of the employee's service and ordinarily takes into account the level of his earnings over a period of time (except in a flat benefit plan). ${ }^{8}$ Over $65 \%$ of the major plans in Alberta (government, university, oil and gas industry plans) fall into the "defined benefit" category of pension plans.

There are three different types of defined benefit plans: the "flat benefit" plan, the "career average" plan and the "final earnings/best earnings" plan:

(1) The "flat benefit" plan provides a retirement pension which "is a specified number of dollars for each year of service, or in rare cases a fixed dollar pension for all employees who retire after completing some minimum period of service". 9 These plans generally have been found in union-negotiated contracts. An example which has been given is that of the plan providing a pension of $\$ 12.00$ per month for each year of service, entitling an employee with 20 years of pensionable service to a pension of $\$ 2,880.00$ per year or $\$ 240.00$ per month. ${ }^{10}$

(2) The "career average" plan provides a retirement annuity which includes for each year of service a percentage of the employee's earnings for that year. For example, if the plan were based on $2 \%$ of the employee's earnings for each year of service, an employee with twenty years of service with career average earnings of $\$ 30,000.00$ would receive a retirement annuity of $\$ 12,000.00$ per year, being $2 \%$ of $\$ 30,000.00$ (or $\$ 600.00$ ) $\times 20$ years.

(3) A "final earnings" pension plan is based on the length of the employee's service and on average earnings over a stated period of time immediately prior to retirement. Typically, the benefit could be based on $1.5 \%$ of the employee's average salary over the five years prior to retirement. If the employee had 20 years of service with an average salary of $\$ 40,000.00$ in the last five years of employment, the final annuity would be $\$ 12,000.00$ per year being $1.5 \%$ of $\$ 40,000.00$ (or $\$ 600.00$ ) $\times 20$ years.

The "best earnings" type of defined benefit plan is based on a similar calculation except that it is the employee's highest earnings years which are

7. See, generally, Laurence E. Coward, Mercer Handbook of Canadian Pension and Welfare Plans (8th ed. 1984).

8. Id. at 13; the "defined benefit" plan should be distinguished from the "defined contribution" plan. Under a "defined contribution" plan an employee receives the retirement annuity which can be bought with the money contributed for the employee's account (by the employer and employee) plus the investment earnings of the contributions.

9. Id.

10. Institute of Law Research and Reform, Matrimonial Property: Division of Pension Benefits upon Marriage Breakdown, Report No. 2, (1985) 18. 
considered. These are usually, but not always, the final earning years.

It is important to note that benefits under the "final earnings" or "best earnings" plans vary with the employee's length of service and the final or best level of earnings. Such plans are quite common. For example, "final" or "best earnings" plans are the type of plan established by both provincial universities and by all local authorities in Alberta, including the Cities of Calgary and Edmonton. According to a survey of Canadian pension plans, approximately $80 \%$ of all defined benefit plan members in Canada are covered by "final earnings" plans."

\section{THE COMPONENTS OF THE PENSION PLAN}

As a "final earnings" type of defined benefit plan, Mr. Tutiah's plan was based on the length of his service and his earnings averaged over a stated period of time immediately prior to retirement. An approximation of his plan is illustrated by Figure 1 (graph) and by Figure 2 ('pie" chart). These figures are representational only as various assumptions about his plan have, of necessity, been included in the calculations. The historical evolution of the values of the "totalled contributions", the contributions with accumulated interest, and the entire pension benefit, are shown on Figure 1 as these values might have appeared to the Court in the Tutiah case had such a graph been available. It is based on 18 years of service, and the final earnings are calculated over the seven years of service immediately prior to the employee's ceasing employment. Assumptions taken into account concern, inter alia, the interest and indexing rates then in force. The contribution rate and benefit formula are based on those of the actual plan as it existed prior to July $1,1980$.

Firstly, Figure 1 demonstrates the difference between Mr. Tutiah's "totalled contributions" (approximated at \$14,800.00) and "accumulated contributions". The latter sum comprises the interest paid on employee contributions over 18 years of service plus the "totalled contributions". The amount of interest accumulated over the years of service is only slightly less than the value of the "totalled contributions", and thus represents a substantial portion of the value of the pension benefit. ${ }^{12}$ This illustrates the importance of the value of credited interest as a component of the value of the total pension benefit.

Secondly, Figure 1 sets forth a representation of the relationship between the value of the total benefit under the plan and the value of the "totalled contributions". A plan paying "over $\$ 500.00$ per month for life" ${ }^{13}$ if retirement occurs at age 55 and paying $\$ 601.00$ per month for life at age 60 would represent a pension benefit value of approximately $\$ 80,000.00$, being the discounted present value ${ }^{14}$ of future pension pay-

11. Financial Executives Institute Canada, Report on Survey of Pension Plans in Canada (1983) 25 , Table 4.

12. The interest rate used for the calculation of the "accumulated contributions" was $8 \%$ based on an average rate of interest over the years $1963-1981$.

13. Supran. 3 at 364.

14. "Discounted present value" means that a discount with respect only to interest is included in the calculation whereas "actuarial present value" implies that the sum is being discounted for more than interest, e.g. for mortality as well. 
ments at each point in the representation of Mr. Tutiah's career. For example, the date of his initial contribution to the pension plan is not known precisely; for the purposes of these calculations it is assumed that his employment with the Board began at or near age 35 and the discounted present value of his pension benefit at that time is shown on Figure 1 as at or near zero. Thus, by age 38 some pension benefit, receivable at a future date, would have been accumulated. 15 This benefit was discounted to permit Figure 1 to provide a representation of the present value of that benefit as if it were viewed at age 38 .

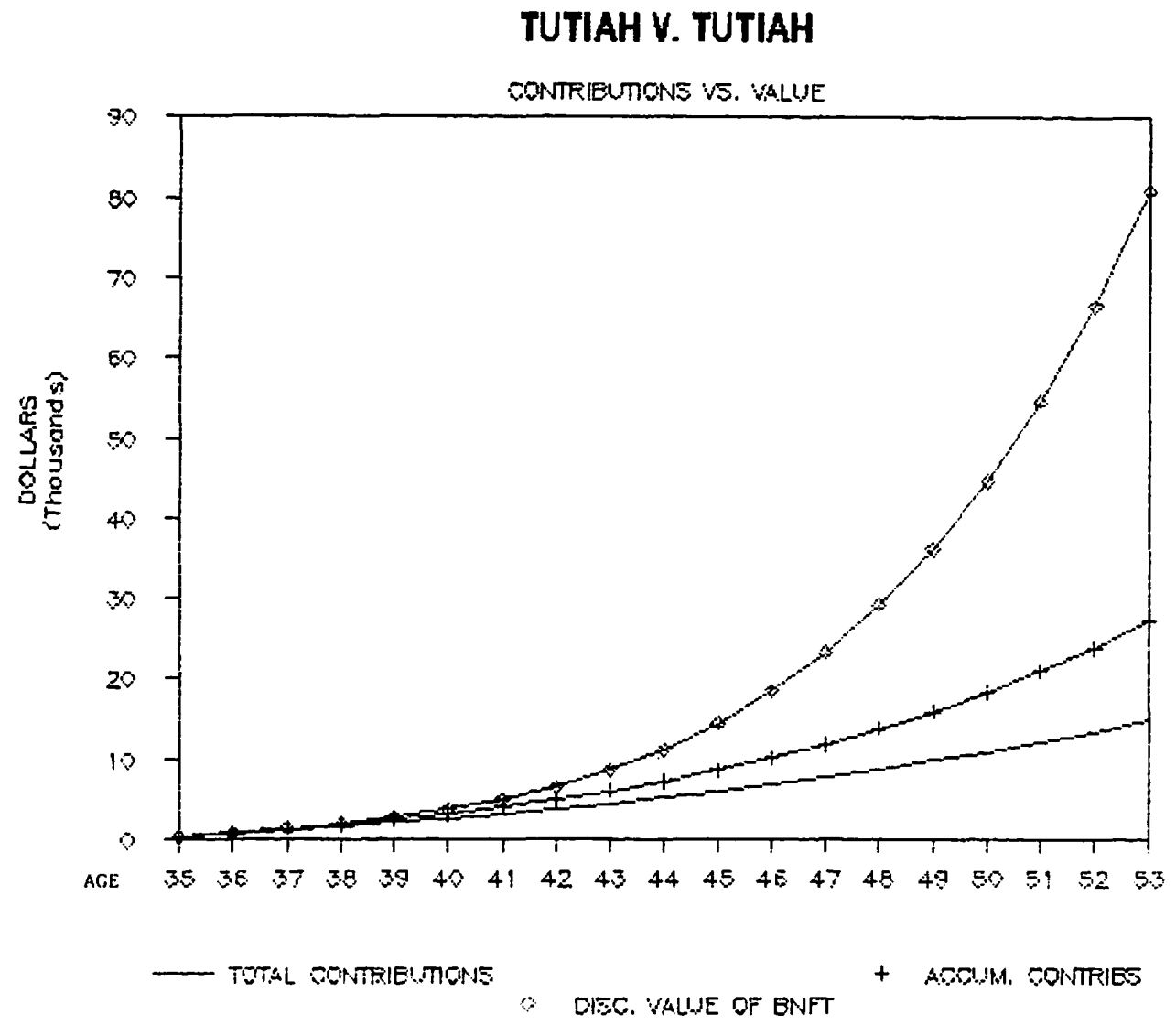

It is apparent that the acceptance of $\$ 14,701.00$ as the value of $\mathrm{Mr}$. Tutiah's pension plan, as Huband J.A. pointed out, "does not reflect the true value of his pension rights". ${ }^{16}$ In fact, the value of "totalled contributions" is approximately one-fifth of the value of the total benefit.

15. Age 55 was used as the future date at which the benefit would be receivable for the purposes of these calculations.

16. Supran. 13. 
FIGURF. 2

\section{TUTIAH V. TUTIAH}

EONTFIEUTONS $\sqrt{ }$. VALUE

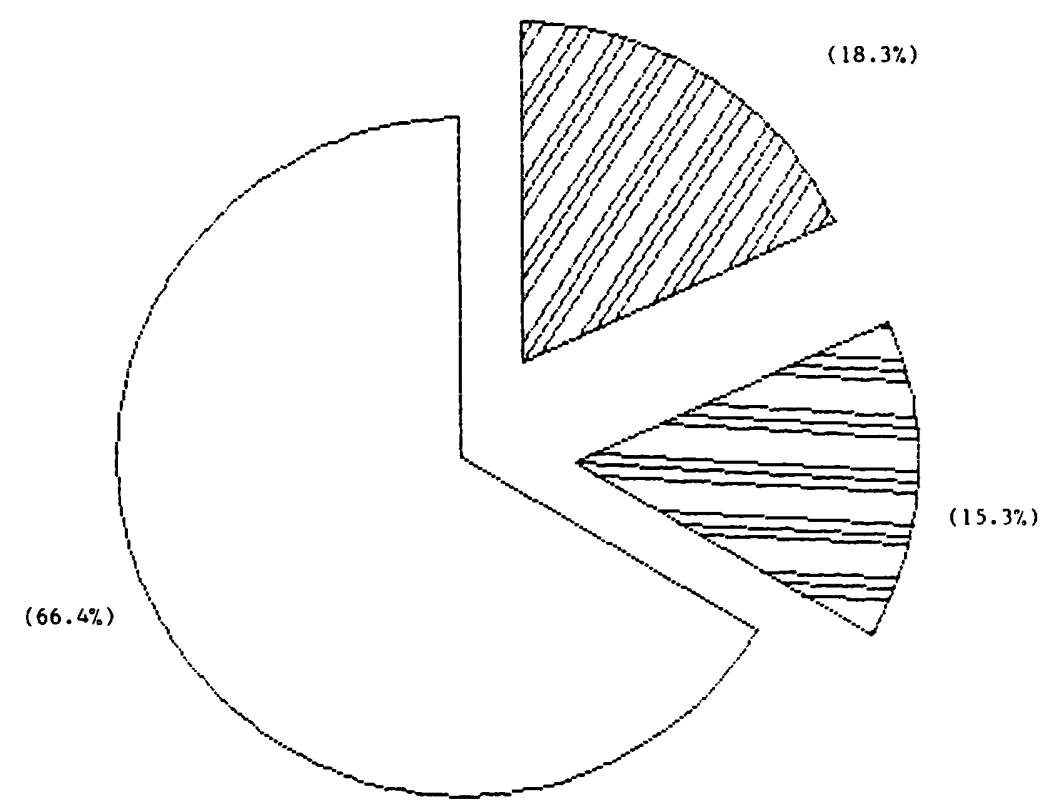

Figure 2, also a representation of Mr. Tutiah's pension benefit, shows the proportions of the components of the pension benefit at age 53 as a percentage of the total value of the pension benefit. Mr. Tutiah's employee contributions approximate $18.3 \%$ of the total value of the pension benefit whereas the interest earned by those contributions represents $15.3 \%$ of that total value. The major portion of the benefit, i.e. $66.4 \%$, approximates the value of the employer's contributions plus interest, if any, earned on those contributions."

This substantial difference between the value of employee contributions and the total value of benefits would exist for any pension plan to which a significant contribution is made by the employer. It is clearly important to recognize the value of all the components of the package of total benefits under the plan, rather than of just the employee contributions.

Accordingly, a careful examination of the information provided by pension plan administrators is necessary to determine the meaning of the facts provided. The letter from the administrators of $\mathrm{Mr}$. Tutiah's pension plan referred to "contributions . . . totalling . . \$14,701.00". The term "totalled contributions" is normally used by actuaries and pension plan administrators to refer to the arithmetical total of the employee contributions only, excluding the value of interest on those contributions, employer contributions or any other benefit. ${ }^{18}$ Notwithstanding that the interest

17. Interest earnings on the employer's contribution would be included in the $66.4 \%$ component where the employer's contribution is allocated to the plan on a periodic basis.

18. Discussions with Keith McComb and Alfred J. Schorath, actuaries consulting to the Pension Plans and Employment Benefits project. 
information is normally readily available, the disclosure obligations of plan administrators may have limitations depending on the particular plan; their individual inclinations to disclose information beyond the requirements under the plan may be variable.

Pension plan administrators do not, ordinarily, provide estimates of the discounted present value of the pension benefit. Actuarial advice must be sought on that point either from the actuary employed by the plan or from an actuary in private practice and, as has been judicially observed, the calculations require a number of assumptions to be made with regard to various contingencies, leading to a less than certain result. ${ }^{19}$ It is for that reason that a division of pension proceeds has been seen, in a number of cases, to be preferable to a division of the actuarial present value of the pension benefit. ${ }^{20}$

Nevertheless any discussion of pension valuation assumes that disclosure of the financial underpinnings of the pension plan has occurred. Where this has not occurred, as in Tutiah, the validity of the marital property settlement may be called into question.

\section{DOMESTIC CONTRACTS}

Case law on the issue of the enforceability of domestic contracts in the absence of full financial disclosure, has generally arisen in the context of spousal maintenance. These cases have implications for the treatment of pension plans as part of matrimonial property settlements.

In Tutiah, the Manitoba Court of Appeal agreed with the trial judge that the settlement offered by the wife and accepted by the husband constituted a spousal agreement within the context of Manitoba's matrimonial property legislation. No basis was found by the majority for setting aside the agreement. Huband and Hall JJ.A. held the view that, in the absence of contrary express statutory provisions, a domestic contract can only be set aside on the basis of traditional contract doctrine. In this case no unconscionability nor undue influence was found. Although simple unfairness would not suffice to avoid the agreement, the majority was of the view that there was no unfairness here, the wife being merely content to settle based on her own valuations. For the same reason, the majority found no mistake which would go to invalidate the contract: the errors in valuation were not material to the formation of the contract since the wife understood that there was some uncertainty about the valuations and could be taken to have placed little reliance on them.

Matas J.A., dissenting, held the opinion that the agreement could be set aside on broad equitable grounds. In his view, the husband had failed in his duty to provide full disclosure of financial information and this resulted in an inequality of bargaining positions between the spouses and an unjust enrichment of the husband. This opinion has been roundly criticized by

19. Moravcik v. Moravcik (1983) 37 R.F.L. (2d) 102 at 107; 29 Alta. L.R. (2d) 207 at 212, 50 A.R. 180 at 183 (C.A.).

20. Id.; McAlister v. McAlister [1983] 2 W.W.R. 8, 23 Alta. L.R. (2d) 141, 41 A.R. 277 (Q.B.); Herchuk v. Herchuk (1983) 35 R.F.L. (2d) 327, [1983] 6 W.W.R. 474, 27 Alta. L.R. (2d) 276, 150 D.L.R. (3d) 366, 48 A.R. 169; revg. 31 R.F.L. (2d) 361, [1983] 2 W.W.R. 222, 44 A.R. 193. 
Professor McLeod as leading to uncertainty in marital property division and as appearing "unwilling to give effect to recent case law and the realities of modern matrimonial law"..$^{21}$

The majority decision, on the other hand, was applauded as being in agreement with the decision of the Ontario Court of Appeal in Farquar v. Farquar. ${ }^{22}$ In that case minutes of settlement were prepared after negotiations between the solicitors of the spouses, which contained a waiver of the wife's right to maintenance. The wife executed the minutes without obtaining disclosure of the husband's financial affairs. The husband had represented to the wife that, notwithstanding his refusal to pay spousal maintenance, he would support her. The wife subsequently applied to vary the decree nisi to provide for spousal support and was successful at trial. The appeal was allowed on the ground that there was no basis in common law or equity to avoid the contract. In particular, the husband's nondisclosure did not constitute a basis for non-enforcement of the contract since full disclosure could have been obtained either upon request or pursuant to ordinary discovery procedures. His representation was found not to have induced the wife to enter into the agreement. Accordingly, no basis for invalidation of the contract was found.

An Alberta decision, Moldaver v. Moldaver, ${ }^{23}$ involved a separation agreement which failed to address the issue of pension entitlement. The agreement referred only to money, household goods and vehicles. Upon the wife's subsequent action for a division of the pension under the Matrimonial Property Act, ${ }^{24}$ it was argued that the separation agreement constituted an "opting-out" contract under ss. 37 and 38 of that Act and, thus, the pension plan was excluded from division.

The Court found that the parties had not addressed their minds to the matter of the pension. Mr. Justice Miller referred to the general rule that a Court has no jurisdiction to interfere with a property distribution made pursuant to a valid separation agreement and noted the exceptions: ${ }^{2 s}$

1. There has been a material withholding of information by one of the parties to the agreement (Couzens v. Couzens (1981), 34 O.R. (2d) 87, 24 R.F.L. (2d) 243, 126 D.L.R.

(3d) 577 (C.A.), Lamers v. Lamers (1978), 6 R.F.L. (2d) 283 (Ont. H.C.));

2. There is evidence of fraud, duress or undue influence (Gauthier v. Gauthier (1982), 29

R.F.L. (2d) 434, 42 N.B.R. (2d) 341, 10 A.P.R. 341 (Q.B.), Valta v. Valta (1978), 2

R.F.L. (2d) 87, 4 B.C.L.R. 107, reversed in part 8 R.F.L. (2d) 132, 9 B.C.L.R. 128, 95

D.L.R. (3d) 409 (C.A.)); or

3. There was a mistake held by both parties as to a material fact (Eaton v. Eaton (1980),

21 R.F.L. (2d) 322 (Ont. H.C.)).

The Court found no equitable or common law basis in traditional contract law upon which the agreement could be avoided. However, the wording of s. 37(1) of the Matrimonial Property Act was interpreted as follows: ${ }^{26}$

21. James G. McLeod, "Annotation" (1985) 48 R.F.L. (2d) 338 at 340.

22. Id.; (1983) 43 O.R. (2d) 423, 35 R.F.L. (2d) 287, 1 D.L.R. (4th) 244 (C.A.).

23. Moldaver (Kennedy) v. Moldaver (1984) 38 R.F.L. (2d) 433 (Alta. Q.B.), 30 Alta. L.R. (2d) 254, 52 A.R. 268, 7 D.L.R. (4th) 417 (sub nom. Moldaver v. Moldaver).

24. R.S.A. 1980 , c. M-9, ss. 7 and 9.

25. Supra n. 23 at 437 (R.F.L.), 258 (Alta. L.R.), 271 - 272 (A.R.), 420 - 421 (D.L.R.).

26. Id. at 440 (R.F.L.), 260 (Alta. L.R.), 273 (A.R.), 423 (D.L.R.). 
In my view, in order to oust the court's jurisdiction with respect to assets not specifically referred to, the court must first be satisfied that the contract was intended to encompass all of the assets classed as matrimonial property.

The agreement was found to encompass only those assets to which it specifically referred since it did not contain provisions, for example, relieving the parties from any and all future claims to property or concluding all of their statutory and legal rights with respect to property. ${ }^{27}$ Accordingly, the pension was found to be subject to distribution.

While the position regarding domestic contracts is that the agreements will, in general, only be avoided in accordance with traditional legal or equitable rules, courts have shown reluctance to take that position as a firm rule. In Farquar, Zuber J.A. said that in addition to the common law and equitable defences to the enforcement of ordinary contracts, "there is a narrow range of cases where a court will relieve against a matrimonial settlement even though the contract is valid." ${ }^{28}$

It is suggested that such reasons are far more likely to arise in the context of agreements as to maintenance than in agreements concerning division of property. ${ }^{29}$ Property agreements are generally legislatively required to conform to certain prescribed standards in order to be enforceable under matrimonial property legislation,,$^{30}$ in addition to the traditional contract law requirements. The implication from Farquar and Tutiah is that an argument in favor of avoiding a property settlement based upon lack of disclosure must rest upon successfully showing that disclosure was obtained but was misleading or that the non-disclosure was material to the contract. It is suggested that spouses who receive legal advice, pursuant to which an agreement is executed, but who fail to obtain disclosure, will find it difficult to claim their lack of knowledge as a basis for invalidating the agreement. It is precisely to ensure certainty of contract with respect to these agreements that the provision of independent legal advice prior to execution is a legislated requirement for enforceability of the agreement.

The difficulty remains that, even where legal advice is sought, spouses like Mrs. Tutiah insist on acting contrary to that advice by declining to obtain disclosure of full financial information. Lawyers have said that even where spouses are advised as to the existence of a pension and are advised to seek a valuation of the pension, the spouses decline to do so because of, among other reasons, a concern over the cost of the assessment. ${ }^{31}$ Even where actuarial advice has been sought, many nonemployee spouses prefer to accept payment of a lump sum now as opposed to payment of a share of the pension benefit as and when received by the employee-spouse. ${ }^{32}$ It is recognized that actuarial assessments of the present value of pension benefits can vary in cost from $\$ 400.00$ to $\$ 1,500.00$, depending on complexity, that a bird in the hand has many

27. Id. at 441 (R.F.L.), 261 (Alta. L.R.), 274 (A.R.), 423 (D.L.R.).

28. Supra n. 22 at 431 (O.R.), 299 (R.F.L.), 252 (D.L.R.).

29. E.g. Jull v. Jull (1985) 34 Alta. L.R. (2d) 252 (Q.B.).

30. E.g. the Alberta Matrimonial Property Act, s. 38, supra n. 24.

31. This comment is based upon discussions with a number of Alberta practitioners with extensive family law practices, which discussions were undertaken for the "Pension Plans and Employment Benefits" project.

32. Id.; similar comments have been received from actuaries. 
advantages and that the division of future proceeds is not free of difficulties. ${ }^{33}$ Nevertheless, it is suggested that pension plans are too important, in the context of personal income security for an aging society, to be lightly bargained away by non-employee spouses.

\section{CONCLUSION}

In conclusion, the Tutiah case demonstrates the difficulties lawyers frequently encounter when discussing pension division with the nonemployee spouse. The non-employee spouse often wants a speedy settlement and is not interested in incurring the costs of obtaining a valuation of pension assets. Even where actuarial advice is sought, it appears that many of these spouses prefer to take a small lump sum now rather than wait for a share of the deferred pension when received. The first step in assessing the role of a pension in a matrimonial property settlement is the valuation of that asset. A recognition of the value of the components that make up the total value of that pension benefit is crucial to reaching an agreement as to such a valuation. It is hoped that the illustrations provided can be of some assistance in demonstrating the extent of benefits to be considered and, in some cases, possibly forfeited. Given the cost and uncertainty of result that is at stake when litigation is subsequently undertaken in the hope of avoiding a previous settlement, it would seem better to convince clients to have their second thoughts before, rather than after, a binding agreement has been reached.

33. Supra n. 10 at $87-104$. 